\title{
Factors Affecting Adoption of Soybean Production Technologies in Tiro Afeta District, Ethiopia
}

\author{
Mideksa Dabessa Iticha \\ Ambo University Waliso Campus School of Business \\ and Economics P.O. Box217, Waliso, Ethiopia
}

\begin{abstract}
Adoption of improved technologies is seen as a key driver to increase agricultural production and productivity in Ethiopia. However, farmers are still using lower than the recommended rates and yet there are a lot of farmers who are not using soybean production technologies at all. In this study, we analyze the factors affecting adoption and intensity of soybean production technologies adoption using a survey data collected from 188 randomly selected smallholder farmers in Tiro Afeta District, Ethiopia. The data were analyzed using descriptive statistics; econometric models and Kendall's Coefficient of Concordance (W) analysis were employed to analyze the data. The result from Heckman two step model indicated that education level of household, total livestock holding, improved seed availability, frequency of extension contact, credit use and farm income were positively and significantly influenced where as market distance negatively and significantly affected adoption of soybean production technologies. Also the, result indicated that age, land holding size, and farm income determine the intensity of soybean technologies adoption positively and significantly whereas distance from market affect negatively and significantly. Based on the findings of this study it can be concluded that policy and development interventions should give emphasis towards improvement of such economical and institutional support system so as to achieve wider adoption of soybean production technologies, to increase production and productivity as well as to ensure food security.
\end{abstract}

Keywords: Adoption, Intensity, Soybean, Technology

DOI: $10.7176 / \mathrm{JBAH} / 10-5-04$

Publication date:March $31^{\text {st }} 2020$

\section{INTRODUCTION}

The world's population is expected to reach 9.1 billion by 2050 ; the production of food, mainly staple crops is expected to increase accordingly (IFC, 2013). This suggests that the dominant role of agriculture as the primary source of food and employment creation in the developing countries' economies should be stepped up. A study by Alexandratos and Bruinsma (2012) indicated that agricultural production needs an increase of $60 \%$ by 2050 to meet the world's consumption demand. Malnutrition and specific nutrient deficiencies are the leading underlying cause of immune deficiency, leading to infections and other diseases. Thus, diversification of food consumed with protein-rich legumes such as soybean is best solutions to protein-calorie malnutrition, particularly in developing countries (Burstin, et al., 2011).

Agriculture is a dominant sector of Ethiopian economy which makes a lion share contribution to the GDP, employment and foreign exchange earnings. It is still believed to remain a sector that plays an important role in stimulating the overall economic development of the country in the years to come. This would be realized if and only if strenuous efforts are made by the government and other concerned stakeholders including farmers to increase agricultural production and productivity (CSA, 2016). Ethiopian economy and employment are largely depending on agriculture sector. Its GDP reached 55 billion USD and per capita was 631 USD by the end of $2013 / 14$. Agriculture, industry and services sectors contributed $40 \%, 14 \%$ and $46 \%$, respectively to the GDP. Despite its declining contribution to GDP over the years, agriculture leading sector in the contribution to the country's overall economy. It is a major source of food, raw material for the domestic industries and commodities export (UNDP, 2016).

Soy bean is relatively new crop in Africa according to (Glycine max L., 2014). Till today, it was seen as being applicable only for large- scale commercial farming for production of seed that are used in making livestock feed. The major soybean producing countries in the world are the United States, Brazil, China, Nigeria, India, Argentina, South Africa and Uganda (IITA, 2009). It is the most important legume worldwide due to its versatile uses as a human food, animal feed and its role in soil amelioration. Soybean can grow in Woina Dega (middle highland) and Kola (low land) areas of the country. Depending on its varieties, the crop grows in an altitude ranging from 700-1800, rain fall 450-1500 mm. Day temperatures ranging from $23-25{ }^{\circ} \mathrm{C}$ are ideal for growing the crop. Potential areas for soybean are: Southern Nations Nationalities People region, Oromia region, Benshangul Gumuze region (Metekel, Kamashe and Asosa areas); Amahara and Tigray regions are expected to be more appropriate for soybean production (Miruts, 2016).

Soybean is a high value and profitable crop. The economic viability of soybean production is determined by the commercial utilization of both its sub-products, meal and oil, which, respectively, account for about two thirds 
and one third of the crop's economic value. Soya bean oil and meal is consumed worldwide as food and animal feedstuff respectively (FAO, 2015). Currently agricultural policy of Ethiopia gives high priority for increasing food production and decreasing malnutrition problems through the promotion of improved production technologies among smallholder farmer in the national extension package. In a similar sense, producing and consuming more soybeans improves the situation of food security as it can provide a nutritious combination of both calorie and protein. It is also cheap and rich source of protein for poor farmers, who have less access to animal source protein, because of their low purchasing capacity. Besides better nutritional status, the crop has a great significance in improving the status of soil nutrients and farming system when grown solely and in combination with cereal crops (CDI, 2010).

Soybean's productivity is low in Ethiopia. Its national average yield is low (1.998ton/ha) which is below the global average 2.31ton/ha (CSA, 2014). The low national yield could be attributed to various reasons. Some of these are related to low adoption of improved soybean production technologies; lack of improved varieties and poor cultural practice (Miruts, 2016). So far, many agricultural technologies have been developed and providing extension service to promote agricultural technologies adoption in the country. Despite such interventions, adoption of agricultural technologies in Ethiopia as a whole is quite poor (FAO, 2010), including Soybean adoption. For example, land improving technologies such as improved seed, fertilizer, improved agronomic practices and natural conservation measures are not widely adopted (Million, 2010).

Even though, a lot of studies have been conducted to explain the factors affecting adoption and intensity of adoption of soybean production technology in Ethiopia at different places and time by using different models, the currently available knowledge about the adoption and intensity of adoption of soybean production technology is not sufficient. This is due to the fact that, factors influencing adoption and intensity of adoption is different from place to place according to the findings of different authors. This indicates that there are different factors directly or indirectly influencing the adoption of technologies that believed to bring change in smallholder farmers' production and productivity. But, the reasons why farmers do not accept the recommended soybean production technologies are not yet well understood. The intensity of adoption of the recommended technologies among farmers has not been determined in the study area. Knowledge of the distribution of the technologies and the factors triggering the technologies is very important in order to make informed policy decisions (Jain et al. 2006). Therefore, this study aimed at analyzing the level to which the recommended soybean production technologies are adopted by farmers and assessing the factors influencing adoption of the recommended technologies in the study area since still now empirical study is not conducted on this problem.

\section{RESEARCH METHODOLOGY}

\subsection{Description of the Study Area}

The study was conducted in Tiro Afeta District, Jimma zone, Oromia regional state, Ethiopia. The District is situated at a distance of $68 \mathrm{~km}$ north east of Jimma town and $263 \mathrm{~km}$ West of Addis Ababa. The administrative town of the District is called Dimtu. The District is consist of 23 rural and 2 urban kebeles and lies at an approximate altitude of 1432-2500m above sea level.

The district has total population of 130,554 of male 66,732 and female 63,822 . The total number of households in the district is about 15,436 of which 14,574 are male headed and 862 are female headed. The economic base of the residents of the District is mixed farming, which the majority of the population depends for their livelihood. Individual smallholder farmers are the sole and dominant production unit. Farming is based on rain fed and is characterized by low productivity. Mixed farm (crop production and animal rearing) is a typical practice in the District. The major crops produced in the District are: maize, sorghum, teff, nugi, wheat, barley and others. .

\subsection{Sampling Method and Procedure}

Two-stage sampling techniques were used to select sampled respondents. In the first, by considering soybean production uniformity in all kebeles of the district from the total of 23 rural kebeles, 3 kebeles were randomly selected. In the second stage, a list of all smallholder soybean farmers in the three kebeles were obtained and stratified into two adopter and non-adopter of soybean technologies and 188 smallholder farmers (97non-adopter and 91 adopter of soybean production technology) were randomly selected from total households of 2352 of the sampled kebeles in the district.

\subsection{Data Type, Sources and Methods of Collection}

Both quantitative and qualitative data were collected from primary and secondary sources. The primary data were collected through structured interview schedule, focus group discussion and key informant interview. The quantitative data were collected through structured questionnaire by trained enumerators from the sampled respondents. For this data collection, eight enumerators and one supervisor were used. The questionnaire was pretested on 20 similar farmers with the sampled household, but who were not included in the final survey, for clarify, 
relevance and completeness. Finally the questionnaire was translated from English to Afaan Oromoo (local language of the study area) and implemented. In addition, primary data were collected from key informants including district administrative bodies, experts from agricultural offices and cooperative offices; as well as from three focus groups (one from each kebele), each consisting of 8 farmers. The secondary data were collected from published and unpublished materials.

\subsection{Methods of Data analysis}

In this study, both descriptive statistics and econometric model were used to analyze the data. Descriptive statistics was used to provide a summary statistics related to variables of interest and Chi-square test and t-test were used to identify variables that vary significantly between adopters and non-adopter.

\subsubsection{Econometric analysis}

In non-experimental data where samples are selected randomly after the population in the sampling frame made their own decisions to participate in a program or not (i.e., self-selected themselves to participate or not), one can't rule out self-selection bias of the program participants in the estimations to be made using these data. Thus, we use Heckman's selection model to control for the selection bias problem. According to Heckman (1979), sample selection bias may arise in practice for two reasons, first; there may be self selection by an individual or data units being investigated; second sample selection decision by analysts or data processors in much the same fashion as self selection. In this study due to the first reason we are enforced to use Heckman two stage models.

Some adoption studies in Ethiopia and East Africa used the Heckman's selection model to identify the probability and intensity of different agricultural technologies in different locations (Jaleta et al., 2013; Yirga and Hasan, 2013; Atupokile, 2016).

Heckman's selection model follows two-steps estimation procedure where in the first stage, an 'adoption equation', attempts to capture factors affecting adoption decision and Inverse Mill's Ratio (IMR) is obtained. In the second stage, the intensity of adoption is estimated using the IMR as one of the explanatory variables to correct selection bias. The probability of adoption was modeled by Maximum Likelihood Probit, from which the inverse Mill's ratio was estimated. The specifications for Heckman's two-step models are as follows:

1. The adoption equation: The Probit model is specified as:

$$
\begin{gathered}
\mathrm{Yi}=\beta \mathrm{iXi}+\varepsilon \mathrm{i}, \mathrm{i}=1,2, \mathrm{n}--- \\
\mathrm{yi}^{*}=1, \text { if } \mathrm{yi}^{*}>0 \text { or } 0, \text { if } \mathrm{yi}^{*}<0
\end{gathered}
$$

Where, $\mathrm{yi}^{*}$ is the latent dependent variable which is not observed and $\mathrm{Yi}$ is a binary variable that assumes 1 if household $\mathrm{i}$, use improved soybean and 0 otherwise.

$\beta \mathrm{i}$ is a vector of unknown parameters in adoption equation.

$\mathrm{Xi}$ is a vector of explanatory variables in the probit regression model.

$\varepsilon_{\mathrm{i}}$ is random error term that are assumed to be independently and normally distributed with zero mean and constant variance. Lambda $(\lambda \mathrm{i})$, which is related to the conditional probability that an individual household was deciding to adopt (given a set of independent variables) is determined by the formula.

$\lambda \mathrm{i}=\frac{f(x \beta)}{1-F(X \beta)}$

Where $\lambda \mathrm{i}$ is Inverse Mill's Ratio (IMR), $\mathrm{f}(\mathrm{X} \beta)$ is the standard normal probability density function and 1-F $(\mathrm{X} \beta)$ is the cumulative distribution function for a standard normal random variable. The value of $\mathrm{Xi}$ is not known, but the parameters $(\beta)$ can be estimated using a probit model based on the observed binary outcome (Yi). Then it was used in outcome equation to make consistency of the model.

2. Regression (OLS): Outcome model is specified as:

$\mathrm{Yi}=\alpha \mathrm{iZi}+\mu \lambda \mathrm{i}+\eta \mathrm{i}$

Where, $\mathrm{Yi}$ is the intensity of soybean adoption technologies, $\alpha \mathrm{i}$ is a vector of unknown parameters to be estimated in the level of soybean adoption technologies equation, $\mathrm{Zi}$ is a vector of explanatory variables determining the rate of soybean adoption, $\mu$ i is the parameter that helps to test whether there is a self-selection bias in the adoption of soybean, $\lambda \mathrm{i}$ is inverse mill ratio and $\eta \mathrm{i}$ is the error term.

Before running the Heckman model all the hypothesized explanatory variables were checked for the existence of multi-co linearity problem. There are two measures that are often suggested to test the existence of multicollinarity. These are: Variance Inflation Factor (VIF) for association among the continuous explanatory variables and contingency coefficients (CC) for dummy variables. In this study, following Maddala (1992) and Gujarati (1995), variance inflation factor (VIF) and contingency coefficients (CC) were used to test 
multicollinearity problem for continuous and for dummy variables respectively.

\section{RESULT AND DISCUSSION}

\subsection{Descriptive Analysis}

Table 2 in Annex presents the results of descriptive statistics and compares the soybean production technologies users and non-users based on different factors. Accordingly, about $83.5 \%$ of the sample households are male headed. More than $76.28 \%$ and $91.2 \%$ of female and male headed households respectively are soybean technology adopters.

The overall average age and education of the sampled respondents were 44.97 and 2.95 years respectively. There is no statistically significant mean difference among adopters ( 43.67 years) and non-adopters (45.71 years) where as adopters are more educated (4.64 years) than non-adopter (1.37years). The average family size is 5.395 in adult which is equally for adopter and for non-adopter.

The average farm size and livestock holding of sampled respondents were $2.87 \mathrm{ha}$ and 6.75 TLU respectively. Non-adopter and adopter holds almost equal farm size which is 2.88 and 2.85 hectares respectively. On the other hand, adopters hold larger livestock (7.75TLU) than non-adopter (5.80TLU).

The average annual farm incomes and off-farm income were 7511.72EB and 665.00ETB (Ethiopian Birr) per household respectively. The mean farm income was larger for adopters (9649.8 EB) than that of non-adopters (5505.8EB). Likewise, the average off-farm income was also larger for adopters (865.99ETB) than for non-user (665.00ETB). The average frequency of extension agent's contact with sample respondent was 2.175 days per month during production season. Users contact extension agents more frequently (3.09 days per month) than nonusers who contact for only 1.32 days per month. On average, a household walks $5.32 \mathrm{~km}$ and non-adopter walk $6.08 \mathrm{~km}$ while adopters were travel $4.51 \mathrm{~km}$ which is less than non-adopters.

In table3 annex from non-user $(57.73 \%)$ and user $(6.6 \%)$ of sampled farmers had perceived that the negative whereas from non-user (42.27\%) and (93.4\%) of users among the sampled farmers had perceived that the cost of production was high. Hence, a chi-square $(\chi 2)$ analysis indicated that there was statistically significant difference in perception on cost of production among adopters and non-adopters at $1 \%$ level.

From non-adopter $77 \%$ and adopter $29.67 \%$ were response that improved soybean seed is not available where as non-adopter $23 \%$ and adopter $70.33 \%$ were response that improved soybean seed is available. Hence, a chisquare $\left(\chi^{2}\right)$ analysis indicated that there was statistically significant difference at among users and non-users $1 \%$ level. From non-adopters $38.47 \%$ and $45 \%$ were a member of cooperative society whereas $61.53 \%$ of non-adopter and $55 \%$ of adopter were not a member of cooperative society.

From non-adopter $47.25 \%$ and adopter $16.5 \%$ were response that has not participated in field day where as from non-adopter $52.75 \%$ and from adopter $83.5 \%$ were responses that participate in field day. Hence, a chisquare $(\chi 2)$ analysis indicated that there was statistically significant difference in perception on perception to ward soybean production technology among adopter and non-adopter at $1 \%$ level. From non-adopters $67 \%$ and adopters $57.73 \%$ were non-users of credit whereas $33 \%$ of no-adopter and $42.27 \%$ of adopters was users of credit.

\subsection{Econometric Model Results}

\subsubsection{Determinants of soybean production technologies adoption decision}

Table 4 in Annex presents the output of Hackman selection model for the factors affecting household's soybean production technology. The result indicated that seven variables affect the probability of soybean production technology.

Education level of household head was found to positively and significantly influence the probability of adoption of soybean production technologies at $1 \%(\mathrm{P}<0.001)$ level of significance. The result indicates that, the increase in the number of years of formal schooling of the head of a household by one more schooling year would lead to increases the probability of soybean production technologies adopt in soybean production by $18.91 \%$. This implies that, having education level of smallholder soybean production farmers will improve the ability to use information, process and interpret information concerning agricultural technology. The result of this study was consistent with the finding by Eba and Bashargo (2014), Afework and Lemma (2015), Sisay (2016) and Abebe (2017) who stated that adoption of agricultural technology was positively associated with level of farmers' education.

Livestock holding was found to be statistically significant variable at $5 \%(\mathrm{P}<0.015)$ level. The result implies that, the increase in livestock holding (in tropical livestock unit) of the head of household by one more TLU would lead to the increases in the probability of soybean technology adoption in soybean production by $11.95 \%$. This implies that, as livestock value increases the income of the smallholder maize farmers increases which leads to increases the purchasing power of soybean production technology of the smallholder soybean farmer. This study was consistent with the research findings by Ketema and Bauer (2011),Yirga and Hassan (2013). Their results suggested that improving herd size (e.g. improving access to veterinary service) will have positive impact on raising adoption and expected use of soybean production technology. 
Improved seed availability was found to be statistically significant variable at $10 \%(\mathrm{P}<0.068)$ level. The result of the study indicated that, being improved seed availability of the head of household would leads to an increase in the probability of soybean production technology in soybean production by $80 \%$. From this result, it can be stated that those farmers who have obtain improved soybean seed are more probability of soybean production technology in soybean production than those not obtain improved soybean seed on time and closest place. In similar result was gained by Adunea (2016) shows provision of improved wheat seed to farmers in required quantity and at the right time increases the probability of adoption of wheat row planting and the intensity of use of wheat row planting technology.

Frequency of contact with extension agent found to be statistically significant at $1 \%(\mathrm{P}<0.004)$ level in affecting the adoption of soybean production technology. The result of the study revealed that, the increase in the frequency of extension agent contact with the head of household by one more day per month would lead to the increase in the probability soybean production technology adoption in soybean production by $27.57 \%$. This result implies that frequency of contact with extension agent was enhanced the exposures of farmers on adoption practices, increases the probability of acquiring updated information on the new agricultural technologies. This study was consistent with research finding carried out by (Dereje et al., 2016). On the basis using the analytical method to analysis extension as a determinant in adoption of soybean production technology was proven to have positive and significant impact.

Distance from market was found to be statistically significant at $1 \%(\mathrm{P}<0.000)$ level in affecting the adoption of soybean production technology. The result of the study indicated that, the increase in the distance from market of household by one more kilometer would lead to the decrease in the probability adoption of soybean production technology by $35.99 \%$. The result implies that since the farmer is far from market cannot obtain enough information about price, quality and have transportation problem. This is in line with previous studies by Debelo (2015) ,Sisay (2016) and Musba (2017), who found that distance to nearest market influence adoption of new technology negatively.

Use of credit was found to be statistically significant at $10 \%(\mathrm{P}<0.060)$ level in affecting the adoption of soybean production technologies. The result of the study indicated that, being user of input credit of the head of household would leads to an increase in the probability of soybean production technology adoption in soybean production by $56.3 \%$. From this result, it can be stated that those farmers who have use formal credit are more probability of soybean production technology adoption in soybean production than those not using formal credit. The result also indicated that credit is very helpful in relieving capital constraints faced by smallholder soybean farmers for adopting soybean production technology and other purchased input. The study is consistent with the findings of Mekuria (2013).

Farm income was found to be positively and statistically significant at $1 \%(\mathrm{P}<0.005)$ level in influencing on the adoption of soybean production technology. Accordingly, as farm income of the head of household increase by one ETB would lead to the increase in the probability of soybean production technology in soybean production by $0.001 \%$. The result of the study implies that, smallholder farmers who got income from their annual agricultural production could invest his/her proportion of income to buy soybean improved seed as well as purchasing other agricultural inputs. Moreover, smallholder farmers with higher annual farm income tend to adopt soybean production technologies. The result is in line with the result found by Mesfin (2017) and Musba (2017), who state that probability of technology adoption and improved varieties of soybean are positively and significantly related.

\subsubsection{Determinants of intensity of Soybean production technologies adoption}

The parameter estimates of Heckman's two step models for intensity of soybean production technology are given in Table 5 in Annex. The results show that five variables are found to be significant determinants of intensity of soybean production technology adoption by households.

Inverse mill ratio (LAMBDA):According to the model output inverse mill ratio (Lambda) for the intensity of soybean production technology was significant, indicating that selection bias would have been resulted if the intensity of soybean production technology had been calculated without taking into account the decision to adopt soybean production technology. That is selection effects become important, the Inverse mill ratio is significant at $5 \%(\mathrm{P}<0.010)$ level. Hence, this justifies the use of heckman's two-step procedure. The negative sign suggested that the error terms in the adoption equation and intensity of adoptions are negatively correlated. This shown that those unobserved factors that determine household adoption of soybean production technologies are likely to be negatively associated with household intensity of soybean production technology adoption.

Age of household head was found to be statistically significant in affecting adoption of soybean production technologies at $10 \%(\mathrm{p}<0.058)$ level. The result of the study indicates that, the increase in the age of household head by one more year would leads to the increase in the intensity of soybean production technology adoption by 0.005 units. This might be related to the reason that older farmers might gain knowledge and learnt though out their long life experience. Moreover, older farmers may accumulate more wealth than younger and so older ones may still be intensive in soybean production technology adoption even as they grow older and again the implication is that the increase in farmer's age increases farmers' experience in farming and understanding more the benefits of 
the technology. Studies by Fitsum (2016), Sisay (2016) and Abebe (2017) also obtained a similar result in their studies.

Total land size holding was found to be statistically significant at $1 \%(\mathrm{p}<0.008)$ level. The result of the study indicates that, the increase in the total land size holding of household head by one more hectare would leads to the increase in the intensity of soybean production technology adoption in soybean production by 0.044 units. This result implies that having large farm size enhances the adoption of agricultural new technology at recommended rate. The result found study consistence with the study of Akubuilo (2013), Mohammed and Lakew (2013), Miruts (2016).

Distance from market was found to be statistically significant at $10 \%(\mathrm{P}<0.065)$ level in affecting the intensity of adoption of soybean production technology. The result of the study indicated that, the increase in the distance from market of household by one more kilometer would lead to the decrease in the intensity of soybean production technology adoption by 0.04 units. The result implies that since the farmer is far from market cannot obtain enough information about price, quality and transportation problem. The result of the study was similar with result of Adunea (2017) increase in distance $(\mathrm{km})$ from the household residency to the nearest market will decrease the intensity of use of wheat row planting in his study.

Farm income was found to be statistically significant at $1 \%(\mathrm{P}<0.005)$ level in influencing on the intensity $o$ $\mathrm{f}$ adoption of soybean production technology. As farm income of the head of household increase by one ETB would lead to the increase in the intensity of soybean production technology by units. The result of the study implies that, smallholder soybean farmers with higher annual farm income tend to adopt soybean production technologies. The study was in line with the result found by Mesfin (2017) on chickpea technologies of adoption intensity positively and significantly and Musba (2017) positively significant on intensity of adoption of soybean improved varieties.

\subsection{Constraints Associated with adoption of soybean production technologies}

Table 6 in annex present the result of the Kendall's coefficient of concordance. The coefficient of concordance calculated was $0.670(67 \%)$. The value indicates the degree of agreement in general to the rankings of the constraints. Therefore, the main constraints put into the following categories based on the identification and rankings by the sampled respondents.

High cost of fertilizer, Lack of credit for input use, High interest rate on the credit, Poor quality of soybean seed, Lack of uniform rain fall distribution, Lack of knowledge on soybean technology use and lack of oxen and poor transportation facilities were ranked from 1 to $8^{\text {th }}$ respectively by sampled respondents. In general, the result of this study was consistent with research finding by (Tirfu, 2011; Basha, 2016; Joseph, 2016).

\section{Conclusions and Policy Implications}

Result of descriptive analysis indicated that a total of $51.6 \%$ of respondents have adopted the soybean production technologies where $48.40 \%$ were non-adopters. The level of soybean production technologies adoption of the sample respondents were indicated that $18.08 \%, 17.02 \%$ and $13.3 \%$ were classified in to low, medium and high rate adopters respectively.

Result from the Heckman two-step model indicated that education of level of house hold, total livestock holding, improved seed availability, frequency of extension contact, credit use, farm income positively and significantly influence adoption were as market distance do negatively and significantly affect soybean production technologies adoption. On the other hand, Age, land holding size, and farm income determine adoption intensity of soybean technologies positively and significantly whereas distance from market affect negatively and significantly. The constraints of adoption and intensity of soybean production technologies were also identified and ranked by the respondents in the study area and there are serious constraints. Hence, concerted efforts should be made to promote the adoption soybean production technologies at recommended rate in soybean production to enhance soybean productivity and profit through overcoming the factors and constraints. These require strengthening the institutional support provided to this sector, such as credit service, cooperative union, research and extension service.

Education level of household plays an enormous role in disseminating technologies such as improved soybean seed and other agricultural inputs. Moreover, education is enabling the farmers to capture information in order to disseminate technologies. It is, therefore, necessary to encourage participation of farmers in basic educational opportunity for enhancing application of soybean production technology and other agricultural technologies.

Adoptions of soybean production technologies are still lagging behind the recommended rates for soybean production. Therefore, farmers should be encouraged to increase use levels of these soybean production technology application in order to optimize crop productivity. Furthermore, the study revealed the importance of taking in to account extension agent contact while advising and delivering soybean production technologies to farmers in various soybean producing districts. This can further maximize the benefit obtained from the application of such soybean production technology. Furthermore, it is necessary to strengthen farmers training centers for enabling 
them to properly demonstrate technologies and at the same time to capacitate farmers on technology utilization by offering training.

\section{REFERENCE}

AbebeGalmesa (2017). Adoption of Improved Soyabean Varieties: The BunoBedele and East Wollega Zones of Oromia Region, Ethiopia (Doctoral dissertation, Haramaya University).

Abebe, A., Hagos, A., Alebachew, H. and Faji, M., (2018).Determinants of adoption of improved forages in selected districts of Benishangul-Gumuz, Western Ethiopia.Tropical Grasslands-ForrajesTropicales, 6(2), pp.104-110.

Afework,H. and Lemma,Z., (2015). Determinants of improved rice varieties adoption in Fogera district of ethiopia. Science, Technology and Arts Research Journal, 4(1), pp.221-228.Agrekon,40(3).

Alexandratos, N., \&Bruinsma, J. (2012).World agriculture towards 2030/2050: The 2012 Revision (ESA WorkingPaper No. 12-03). Rome: Food and Agriculture Organization of the United Nations (FAO), Agricultural Development Economics Division.

Atupokile, M. (2016). Adoption of improved maize varieties in northern and Eastern zones of Tanzania (Doctoral dissertation, Sokoine University of Agriculture).

Burstin J, Gallerdo K, Mir RR, Varshney RK, Due G(2011), Improving protein content and nutritional quality. In: A Pratap, J Kumar (eds) biology and breeding of food legumes, chapter 20.

CSA (Central Statistical Agency) (2016). Agricultural sample survey 2015/16 (2008E.C): volume v- report on area, production and farm management practice of belg season crops for private peasant holdings. Statistical Bulletin, Central Statistical Agency, Addis Ababa, Ethiopia.

Dereje Derso, Edo Elemo and Yenesaw Sawnet, 2016. Determinants of the utilization of agricultural inputs and transfer of agricultural technologies. Journal of Agricultural Research and Development Vol. 6(2). pp. 030033, August, 2016

Heckman, J.J.(1979). Schools, skills, and synapses.Economic inquiry, 46(3), pp.289-324.

IFC. (2013). working with Smallholders: A hand for Firms Building Sustainable Supply Chains. Washington D.C: International Finance Corporation, World Bank Group.

IITA (2009) International Institute of Tropical Agriculture, International Institute of Tropical Agriculture (PTA) 2009.lbadan. Nigeria. ISBN 978-131-333-1 Ijere, M.O, (1992) Leading Issues in Rural Development. Enugu Acena Publishers,Pp.1-8.

Jaleta, Moti, ChilotYirga, MenaleKassie, Hugo De Groote, and BekeleShiferaw (2013).Knowledge, adoption and use intensity of improved maize technologies in Ethiopia (No. 309-2016-5268).

MusbaKedir (2017). Adoption and Impact of Improved Soybean (Belessa-95) Variety among Smallholder Farmers in BambasiWoreda, BenishangulGumuz Regional State (Doctoral dissertation, Haramaya University)

LakewWondimu and Mohammed Edris(2013). Are fertilizers and improved seeds complimentary or substitute in the process of adoption: case study of northern Ethiopia.Wudpecker journal of agricultural research.Vol.2(11), pp.286-293.

MirutsFitsum(2016). "Analysis of the Factors Affecting Adoption of Soybean Production Technology in Pawe District, Metekele Zone of BenshangulGumuz Regional State, Ethiopia." World Scientific News 53(3): 122137.

SisayDebebe. 2016. Agricultural technology adoption, crop diversification and efficiency ofmaize-dominated smallholder farming system in Jimma Zone, South-WesternEthiopia. PhD Dissertation, Haramaya University, Ethiopia.

UNDP (United Nations Development Program). 2015. Ethiopia: Key economic and social indicators. Report No. 2, 2015, UNDP Ethiopia, Addis Ababa, P.O.Box 5580.

\section{Annex}

Dependent variable

\begin{tabular}{lll}
\hline Variables & Type/Unit & Description \\
\hline Use/Adoption & Dummy & Status of use/adoption; 1 user \&0 otherwise \\
Intensity of use & Adoption index & Extent of adoption of soybean production technology component \\
\hline
\end{tabular}


Table1: Summary of independent variables, their definition and expected sign

\begin{tabular}{|c|c|c|c|}
\hline Definition of variables & $\begin{array}{l}\text { Nature of } \\
\text { the variables }\end{array}$ & Unit of measurements & $\begin{array}{l}\text { Expected } \\
\text { sign }\end{array}$ \\
\hline Age of the household head & Continuous & Number of years & - \\
\hline Sex of the household head & Dummy & $\begin{array}{l}1 \text { if the household head is male and } \\
0 \text { otherwise }\end{array}$ & + \\
\hline Education level of household head & Continuous & Grade attended & + \\
\hline Family size & Continuous & Measured in adult equivalent & + \\
\hline Perception of farmers $/ \mathrm{hh}$ & Dummy & $\begin{array}{l}1 \text { if perceived as a technology has } \\
\text { positive attributes; } 0 \text { otherwise. }\end{array}$ & + \\
\hline Land holding & Continuous & Hectare & - \\
\hline Number of livestock & Continuous & Number of livestock in TLU & + \\
\hline Frequency of Contacts with extension agents & Continuous & Number & + \\
\hline Participation in soybean field days & Dummy & $\begin{array}{l}1 \text { if participated in soybean field } \\
\text { day and } 0 \text { otherwise }\end{array}$ & + \\
\hline Distance to the main market & Continuous & Kilometer & - \\
\hline Credit use & Dummy & 1 , if yes; 0 , otherwise & + \\
\hline Membership in cooperative societies & Dummy & 1 if member and 0 otherwise & + \\
\hline Off farm Income & Continuous & ETB & + \\
\hline Farm income & Continuous & ETB & + \\
\hline $\begin{array}{l}\text { Availability of } \\
\text { improved soybean }\end{array}$ & $\begin{array}{l}\text { Dummy } \\
\text { variable }\end{array}$ & 1 , if available, 0 , Otherwise & + \\
\hline
\end{tabular}

Table2 in annex Households' socio-economic characteristics (for continuous explanatory variables)

\begin{tabular}{lccccccc}
\hline Variables & \multicolumn{2}{c}{$\begin{array}{c}\text { Non-adopter(97) } \\
\text { Mean }\end{array}$} & Std.D & \multicolumn{2}{c}{ Adopter(91) } & T-value & \multicolumn{2}{c}{ Total sample(188) } \\
Mean & Std.D & & Std.D \\
& & & & & & & \\
Age of household & 43.67 & 6.30 & 45.71 & 6.46 & -1.198 & 44.72 & 6.45 \\
Education level & 4.63 & 2.66 & 1.37 & 2.09 & $9.37 * * *$ & 2.95 & 2.89 \\
Adult equivalent & 5.23 & 1.47 & 5.35 & 1.61 & -0.55 & 5.29 & 1.54 \\
Total land size holding & 2.88 & 1.45 & 2.85 & 1.43 & -0.143 & 2.87 & 1.44 \\
Livestock holding & 5.8 & 2.97 & 7.75 & 4.22 & $3.66 *$ & 6.74 & 3.75 \\
Off-farm income & 665.00 & 2154.02 & 865.99 & 2569.4 & -0.583 & 762.29 & 2359.9 \\
Contact with extension & 1.32 & 1.33 & 3.08 & 2.00 & $7.15^{* * *}$ & 2.17 & 1.9 \\
Distance from market & 6.08 & 2.02021 & 4.51 & 1.5 & $6.04 * * *$ & 5.32 & 1.94 \\
Farm income & 5505.8 & 5730.02 & 9649.8 & 5829.5 & $4.914 * * *$ & 7511.72 & 6125.6 \\
\hline
\end{tabular}

*** \& * significant at $1 \%$ \& $10 \%$ respectively

Table3: Household socio economic character (for dummy variable)

\begin{tabular}{|c|c|c|c|c|c|c|c|c|}
\hline \multirow[t]{2}{*}{ Variable } & & \multicolumn{2}{|c|}{ Non-adopter } & \multicolumn{2}{|c|}{ Adopter } & \multirow[t]{2}{*}{$\mathrm{X}^{2}$ - Value } & \multicolumn{2}{|c|}{ Total sample } \\
\hline & & $\mathrm{N}$ & $\%$ & $\mathrm{~N}$ & $\%$ & & $\mathrm{~N}$ & $\%$ \\
\hline Household perception to & Negative & 56 & 57.73 & 6 & 6.7 & $55.55 * * *$ & 62 & 33 \\
\hline ward soybean & positive & 41 & 42.27 & 85 & 93.4 & & 126 & 67 \\
\hline Improved soybean seed & No & 70 & 77 & 27 & 29.67 & $33.95 * * *$ & 97 & 51.6 \\
\hline availability & Yes & 27 & 23 & 64 & 70.33 & & 91 & 48.4 \\
\hline Member of & No & 56 & 61.53 & 50 & 55 & 0.15 & 106 & 56.4 \\
\hline society & Yes & 41 & 38.47 & 41 & 45 & & 82 & 43.6 \\
\hline Household participation in & No & 43 & 47.25 & 16 & 16.5 & $15.599 * * *$ & 59 & 31.4 \\
\hline field day & Yes & 54 & 52.75 & 75 & 83.5 & & 129 & 68.6 \\
\hline Credit use & No & 36 & 33 & 35 & 42.27 & 0.036 & 71 & 37.8 \\
\hline & Yes & 61 & 67 & 56 & 57.73 & & 117 & 62.2 \\
\hline
\end{tabular}

\footnotetext{
$* * *$ significant at $1 \%$
} 
Table4: Parameter estimates of Heckman's two steps for the likelihood of soybean production technology adoption (Probit estimation) and its marginal effect.

\begin{tabular}{lllll}
\hline Variables & Coef. & Std. Err. & T-ratio & Marginal effect \\
Age of household head & -0.025 & 0.0173 & 1.40 & -0.024 \\
Sex of household head & 0.638 & 0.409 & 1.56 & 0.638 \\
Adult equivalent labor & 0.143 & 0.102 & 1.40 & 0.143 \\
Education level of household head & 0.189 & 0.057 & $3.31^{* * *}$ & 0.189 \\
Livestock holding & 0.119 & 0.049 & $2.43^{* *}$ & 0.119 \\
Total land holding size & 0.0598 & 0.085 & 0.70 & 0.0598 \\
Perception of household head on soy bean & 0.611 & 0.485 & 1.26 & 0.611 \\
Improved seed availability & 0.800 & 0.438 & $1.83 *$ & 0.800 \\
Frequency of contact with extension agent & 0.276 & 0.097 & $2.86 * * *$ & 0.276 \\
Off-farm income & -0.0001 & 0.0001 & -1.50 & -0.0001 \\
Distance from market & -0.36 & 0.086 & -4.19 & -0.36 \\
Member of cooperative society & 0.045 & 0.30 & 0.15 & 0.045 \\
Household field day participation & -0.220 & 0.50 & 0.44 & -0.220 \\
Use of credit & 0.563 & 0.302 & $1.86 *$ & 0.563 \\
Farm income & 0.0001 & 0.00003 & $2.80 * * *$ & 0.0001 \\
Constant & -1.202 & 1.092 & -1.10 & -1.202 \\
\hline
\end{tabular}

Number of obs $=188 \quad$ Wald chi2 $(14)=27.98$ Prob $>$ chi2 $=0.0000$

$* * *, * *$ and ${ }^{*}$ shows the values of statistically significant at $1 \%, 5 \%$ and 10 probability level of significance respectively.

Table5: Parameter estimates of Heckman's two steps intensity of soybean production technology adoption(OLS estimation).

\begin{tabular}{llll}
\hline Variables & Coef. & Std. Err. & T-ratio \\
\hline Age of household head & 0.005 & 0.003 & $1.90^{*}$ \\
Sex of household head & 0.076 & 0.087 & 0.87 \\
Adult equivalent labor & -0.007 & 0.0175 & -0.40 \\
Education level of household head & 0.00023 & 0.0114 & 0.02 \\
Livestock holding & -0.01 & 0.008 & -1.25 \\
Land size holding & 0.0445 & 0.017 & $2.66^{* * *}$ \\
Perception of household head toward soy bean & 0.027 & 0.076 & 0.35 \\
Frequency of contact with extension agent & 0.0002 & 0.015 & 0.0 .01 \\
Off-farm income & $4.10 \mathrm{e}-06$ & 0.00001 & 0.38 \\
Distance from market & -0.0386 & 0.021 & $1.85^{*}$ \\
Member of cooperative society & 0.058 & 0.066 & 0.88 \\
Household field day participation & 0.0142 & 0.077 & 0.18 \\
Use of input credit & 0.037 & 0.0596 & 0.62 \\
Farm income & .00001 & $5.01 \mathrm{e}-06$ & $2.48^{* *}$ \\
Inverse mill ratio (Lambda) & -0.246 & 0.095 & $2.59^{* *}$ \\
Constant & -0.0566 & 0.22 & -0.26 \\
\hline
\end{tabular}

Number of obs $=188$ (regression model with sample selection) Censored obs $=97$

Uncensored obs $=91$ Wald chi2 $(14)=27.98 \quad$ Prob $>$ chi2 $=0.0000$

***' and ** show the values of statistically significant at $1 \%, 5 \%$ and $10 \%$ probability level of significance respectively.

Table 6: Rankings of constrains of adoption and intensity of soybean production technologies adoption by respondents

\begin{tabular}{|lcc|}
\hline Constraints & Mean Rank & Overall rank \\
\hline High cost of inorganic fertilizer & 1.68 & $1^{\text {st }}$ \\
Lack of credit for input & 2.27 & $2^{\text {nd }}$ \\
High interest rate on credit & 3.72 & $3^{\text {rd }}$ \\
Poor quality of soybean seed & 4.10 & $4^{\text {th }}$ \\
Rain fall fluctuation & 4.35 & $5^{\text {th }}$ \\
Lack of knowledge on soybean production technologies & 6.09 & $6^{\text {th }}$ \\
Lack of oxen & 6.47 & $7^{\text {th }}$ \\
Poor transportation system & 7.33 & $8^{\text {th }}$ \\
\hline
\end{tabular}

Note: Kendall's $\mathrm{W}=0.670, \mathrm{M}=188, \mathrm{n}=8, \chi 2=885.285$, Asympt. $\operatorname{sign}=0.000, \mathrm{df}=7$ 